\title{
Hydroxyurea appears beneficial in patients with beta-thalassaemia major and intermedia
}

\author{
S Fadilah S Abdul Wahid ${ }^{1,2}$, Rozilaila Rahmat ${ }^{1}$, Shamsul Azhar ${ }^{3}$, Noor Hamidah Hussin ${ }^{4}$, Cheong Soon Keng
}

\begin{abstract}
Abstrak
Pasien dengan kelainan bawaan pada rantai $\beta$-globin mungkin mengalami gejala penyakit yang lebih ringan jika mereka menghasilkan hemoglobin fetal $(\mathrm{HbF})$ dengan kadar yang tinggi. Penggunaan hydroxyurea $(\mathrm{HU})$ telah memperlihatkan peningkatan kadar HbF pada pasien penyakit 'sickle cell', dan mungkin berguna pada $\beta$-talassemia. Kami memberi terapi HU kepada 13 pasien $\beta$-talassemia intermedia atau mayor, termasuk 6 pasien splenektomi. Pasien-pasien diberi dosis eskalasi (10 sampai 25 $\mathrm{mg} / \mathrm{kg} / \mathrm{h}$ ) HU selama sekitar 2 tahun (median: 21 bulan, 'range': 8 - 55 bulan). Sebelas pasien menunjukkan respons kenaikan HbF pada pra-transfusi, masing-masing dari median awal 8,0\% (2,5 - 61,3\%) menjadi 28,0\% (6,6 - 49,2\%) dan 40,7\% (4,8 - 72,3\%) pada 3 bulan dan 18 bulan pasca terapi HU. Kenaikan yang sama pada nilai median Hb terlihat pada 1, 3 dan 18 bulan terapi HU. Enam dari 7 pasien yang tergantung transfusi yang menunjukkan kenaikan HbF (seorang dengan $\beta$-thalassemia mayor), juga memperlihatkan penurunan kebutuhan transfusi setelah dua tahun terapi HU. Respons terhadap HU juga terlihat dengan adanya pengecilan limpa. Selain ulkus di mulut yang menghilang dengan penurunan dosis HU, tidak terlihat toksisitas lain yang bermakna. Dapat disimpulkan bahwa pemberian $H U$ pada pasien $\beta$-thalassemia menyebabkan peningkatan produksi HbF disertai perbaikan pada eritropoiesis, tanpa toksisitas yang bermakna. (Med J Indones 2007; 16:78-83)
\end{abstract}

\begin{abstract}
Patients with severe inherited $\beta$-globin chain disorders may have milder illness if they produce high levels of fetal hemoglobin (HbF). Hydroxyurea $(\mathrm{HU})$ has been shown to enhance HbF levels in patients with sickle cell disease and may be useful in $\beta$-thalassemias. We administered $H U$ to 13 patients with $\beta$-thalassemia intermedia or major, including 6 splenectomized patients. The patients received escalating doses (10 to $25 \mathrm{mg} / \mathrm{kg} / \mathrm{d}$ ) of $\mathrm{HU}$ for around 2 years (median: 21 months, range: 8 - 55 months). Eleven patients responded with an increase in the pre-transfusion $\mathrm{HbF}$ levels, from a base line median of $8.0 \%(2.5-61.3 \%)$ to $28.0 \%$ (6.6 - 49.2\%) and $40.7 \%$ (4.8 - $72.3 \%$ ) at 3 months and 18 months post-HU, respectively. A concomitant increment in median hemoglobin levels was noted at 1, 3 and 18 months of HU therapy. Six of 7 transfusion-dependent patients who had an increment of $\mathrm{HbF}$ (one with $\beta$-thalassemia major) also had reduced transfusion requirement over the 2-year period of $H U$ therapy. Response to $H U$ was also shown by a reduction in spleen size. Apart from oral ulcers that resolved upon dose reduction of $H U$, no significant toxicity was noted. We conclude that increased HbF production in $\beta$-thalassemia patients, with an improvement in erythropoiesis, can be achieved using HU with minimal toxicity. (Med J Indones 2007; 16:78-83)
\end{abstract}

Keywords: fetal hemoglobin $(H b F)$, erythropoiesis, toxicity

$\beta$-thalassemia is the most common inherited blood disorders in South Asia that results from a number of genetic

1 Clinical Hematology and Stem Cell Transplantation Services, Hospital Universiti Kebangsaan Malaysia, Kuala Lumpur, Malaysia

${ }^{2}$ Department of Medicine, Faculty of Medicine, Universiti Kebangsaan Malaysia, Kuala Lumpur, Malaysia

${ }^{3}$ Department of Community Health, Faculty of Medicine, Universiti Kebangsaan Malaysia, Kuala Lumpur, Malaysia

${ }^{4}$ Department of Pathology, Faculty of Medicine, Universiti Kebangsaan Malaysia, Kuala Lumpur, Malaysia

${ }^{5}$ Department of Medicine, International Medical University, Seremban, Malaysia defects in $\beta$-globin gene expression. ${ }^{1}$ Deficient synthesis of $\beta$-chain leads to imbalance globin chain synthesis with an excess of $\alpha$-globin, which precipitates, causing ineffective erythropoiesis and shortened survival of red cells. Patients with severe $\beta$-thalassemia require regular red cell transfusion to sustain their lives. ${ }^{2}$ However, most individuals so affected usually die before the age of 25 as a direct result of cardiac iron deposition unless treated concomitantly with chelation therapy. ${ }^{3}$ Thus, an important caveat in the management of $\beta$-thalassemia is to find an alternative approach to red cell transfusion. 
Hydroxyurea (HU) is one of several agents capable of activating the $\gamma$-globin gene associated with an improvement in $\alpha$ :non- $\alpha$ globin ratios, thereby leading to an increase in the effectiveness of erythropoiesis after several months of therapy. ${ }^{2,4}$ Because it has the lowest toxicity profile ${ }^{2}$ among the chemotherapeutic agents thus far employed, HU has been widely used for this purpose. Numerous studies have demonstrated that $\mathrm{HU}$ therapy can enhance $\mathrm{HbF}$ production and ameliorate the clinical course of sickle cell disease (SCD) with three or more painful crises per year with only mild myelotoxicity. ${ }^{5}$ However, there has been limited and mainly negative information on the effect of $\mathrm{HU}$ in thalassemia. ${ }^{6}$ Therefore, we undertake this study to gain a better understanding on the effects and safety of $\mathrm{HU}$ in $\beta$ thalassemia patients.

\section{METHODS}

Upon obtaining approval from institutional review board and ethics committee at the Faculty of Medicine, Universiti Kebangsaan Malaysia and informed consent, $\mathrm{HU}$ was administered according to the NIH protocol ${ }^{7}$ to consecutive patients with $\beta$-thalassemia. All of them were treated at the outpatient Hematology clinic of Hospital Universiti Kebangsaan Malaysia (Kuala Lumpur, Malaysia) with regular follow-up every 2 to 4 weeks.

The patients were initially treated with a dose of $\mathrm{HU}$ of approximately $10 \mathrm{mg} / \mathrm{kg} / \mathrm{day}$ (rounded up to the next $500 \mathrm{mg}$ ) in one dose orally over 4 consecutive days/week, and in the absence of hematologic toxicity the dose was increased by $5 \mathrm{mg} / \mathrm{kg} /$ day every 4 weeks to a maximal total dose of $25 \mathrm{mg} / \mathrm{kg}$ (rounded up to 1 to $1.5 \mathrm{~g}$ ) daily and continued for around 2 years. Evidence of hematologic toxicity was defined as a white blood cell count (WBC) of less than $4 \times 10^{9} / \mathrm{L}$ (or neutrophil count of less than $1 \times 10^{9} / \mathrm{L}$ ) or platelet count (PC) of less than $80 \times 10^{9} / \mathrm{L}$. The levels of pretransfusion $\mathrm{Hb}$ and $\mathrm{HbF}$, full blood count, serum $\mathrm{LDH}$ levels, serum bilirubin and spleen size were evaluated before and every 2 to 4 weeks during treatment and the study was conducted from 2001 to 2005 . HbF quantitation was performed using the highperformance liquid chromatography.

Data collected were analyzed using SPSS-PC (version 13.0) for windows. Statistical analysis to determine differences between the data sets depended on the type of distribution and variance. When the distributions were normal and the variances were homogenous, time series analysis of variance (ANOVA) would be used to determine the differences between the data sets. However, when the distributions were not normal or the variances not homogenous, statistical method used to determine the significance of the differences between the data sets and the baseline data was the Wilcoxon Signed Rank Test and $P$ values of $<0.05$ were considered significant.

\section{RESULTS}

We got 13 patients with $\beta$-thalassemia (5 patients with $\beta$-thalassemia major and 8 with $\beta$-thalassemia intermedia), including 6 patients who had prior splenectomy. There were 8 males and 5 females, aged between 15 to 52 years (mean $\pm \mathrm{SD}=28.4 \pm 13.6$ ).

We treated the 13 patients with escalating doses of HU for a median of 21 (range: 8 - 55) months. Ten of thirteen patients responded with a mean increase of $56 \%$ in pre-transfusion $\mathrm{HbF}$ levels, from a baseline median (range) of $8.0 \%(2.5-61.3 \%)$ to $20.1 \%$ (3.0 $80.3 \%$ ) after 6 months of treatment and 33.9\% (2.6 $81.5 \%$ ) at 12 months post-HU, respectively (Figure 1). The median (range) of $\mathrm{HbF}$ level started to increase as early as 3 months post-HU to $28.0 \%$ (6.6 49.2\%) with the highest level noted at 18 months post-HU that was $40.7 \%(4.8-72.3 \%)$ and remained elevated at 2 years of HU therapy that was $39.9 \%$ (39.4 - 51.5\%). Three patients with $\beta$-thalassemia intermedia did not show a consistent pattern of increment and were labeled as non-responders to HU therapy.

Apart from the age, the data analysed in this study did not follow a normal distribution. Therefore statistical method used to determine the significance of the differences in the paired sets of data (between baseline data and data after therapy) was the Wilcoxon Signed Rank Test and $P$ values of $<0.05$ were considered significant.

Increment in median $\mathrm{HbF}$ levels was observed at 3 months of $\mathrm{HU}$ therapy in patients with prior splenectomy and at 12 months of HU in patients with $\beta$-thalassemia intermedia and patients who had undergone splenectomy $(P<0.05$, Table 1,2$)$. Six of 7 transfusion-dependent patients who experienced an increment of $\mathrm{HbF}$ also had reduced red cell transfusion requirement after HU therapy. Over a 2-year period of HU therapy, all $5 \beta$-thalassemia intermedia patients who were transfusion-dependent had a median reduction of $350 \mathrm{mls}$ of a 2 monthly red-cell 
transfusion while one $\beta$-thalassemia major patient had a median reduction of $500 \mathrm{mls}$ of a 2 monthly red-cell transfusion. The increment in the median [range] of pre-transfusion hemoglobin $(\mathrm{Hb})$ level began at onemonth post-HU $(8.4 \mathrm{~g} / \mathrm{dL}[6.8-11.5 \mathrm{~g} / \mathrm{dL}])$ and peaked at 3 months $(8.7 \mathrm{~g} / \mathrm{dL}[6.0-11.4])$; compared to the median [range] of baseline level of below $7 \mathrm{~g} / \mathrm{dL}(6.7$ $\mathrm{g} / \mathrm{dL}[5.7-10.8])$, there were significant differences $(P<0.05)$. The median [range] of $\mathrm{Hb}$ level continued to increase at 12 months, then declined at 18 months of $\mathrm{HU}$ therapy to $7.3 \mathrm{~g} / \mathrm{dL}[5.0-10.0 \mathrm{~g} / \mathrm{dL}]$ and in one patient with $\beta$-thalassemia intermedia the $\mathrm{Hb}$ levels dropped to below the baseline levels at 24 months post-HU (Figure 2).
Increment in median $\mathrm{Hb}$ levels was observed in patients with $\beta$-thalassemia intermedia and $\beta$ thalassemia major at 3 months of HU therapy and in patients with prior splenectomy at 3 and 12 months of HU therapy $(P<0.05$, Table 1,2$)$. The MCV and $\mathrm{MCH}$ started to increase in the first month after HU commencement with a maximum increase at 3 to 6 months of HU therapy $(P<0.05)$ and MCV remained increased at 24 months of therapy and the increment was more prominent in patients with $\beta$-thalassemia intermedia and patients without prior splenectomy. Although not statistically significant, we observed a downward trend in the serum LDH and unconjugated bilirubin levels.

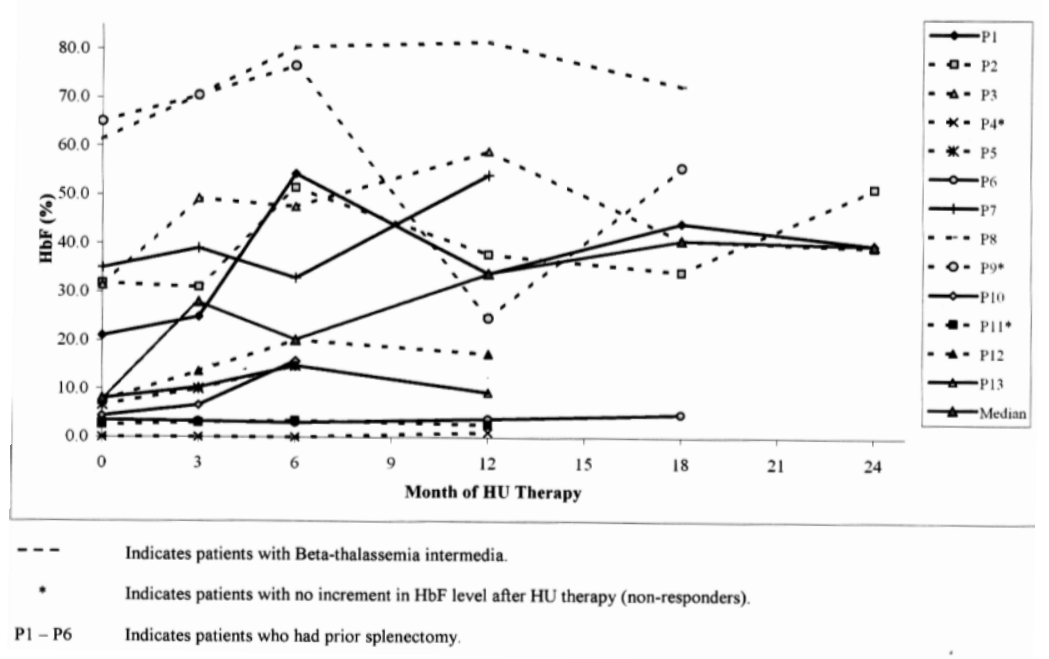

Figure 1. Changes in the level of pre-transfusion $\mathrm{HbF}$ in patients with $\beta$-thalassemia treated with $\mathrm{HU}$
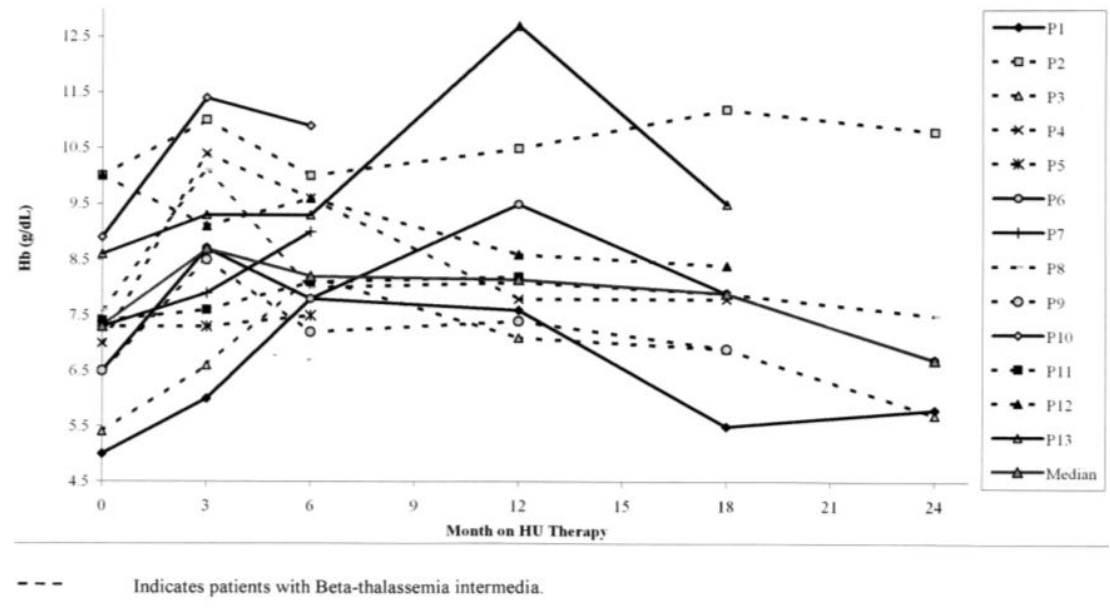

P1 - P6 Indicates patients who had prior splenectomy.

Figure 2. Changes in the level of pre-transfusion $\mathrm{Hb}$ in patients with $\beta$-thalassemia treated with $\mathrm{HU}$ 
The reduction in the spleen size was noted after 6 months of $\mathrm{HU}$ and was most prominent at 12 months of $\mathrm{HU}$ therapy. Most patients also reported an improvement in well being and effort tolerance. There was no significant decline in the WBC and PC in all 4 groups of patients (Table 1,2). Other adverse effects reported included skin hyper pigmentation in a patient and oral ulcers in 2 patients that resolved upon dose reduction of $\mathrm{HU}$.

Table 1. Pre-transfusion data in patients with $\beta$-thalassemia intermedia and major treated with $\mathrm{HU}$

\begin{tabular}{|c|c|c|c|c|c|c|c|}
\hline Parameters & $\begin{array}{c}\text { Baseline } \\
\text { (median, range) }\end{array}$ & $\begin{array}{l}3 \text { months on } \mathrm{HU} \\
\text { (median, range) }\end{array}$ & $P$ value & $\begin{array}{l}12 \text { months on } \mathrm{HU} \\
\text { (median, range) }\end{array}$ & $P$ value & $\begin{array}{c}18 \text { months on } \mathrm{HU} \\
\text { (median, range) }\end{array}$ & $P$ value \\
\hline \multicolumn{8}{|c|}{$\beta$-thalassemia intermedia (8 patients) } \\
\hline $\mathrm{HbF}(\%)$ & $19.5,2.5-61.3$ & $31.0,10.0-49.2$ & 0.285 & $37.8,3.4-80.3$ & $0.043 *$ & $40.7,34.2-72.3$ & 0.109 \\
\hline $\mathrm{Hb}(\mathrm{g} / \mathrm{dL})$ & $7.4,5.4-10.0$ & $8.8,6.6-11.0$ & $0.043 *$ & $8.1,7.1-10.5$ & 0.175 & $7.9,6.9-11.2$ & 0.345 \\
\hline $\operatorname{MCV}(\mathrm{fl})$ & $80.6,61.7-84.4$ & $87.3,70.0-96.2$ & $0.017 *$ & $82.4,66.8-88.7$ & $0.043^{*}$ & $82.5,66.8-88.7$ & $0.028 *$ \\
\hline $\mathrm{MCH}(\mathrm{pg})$ & $26.9,18.7-30.5$ & $28.9,21.9-34.6$ & $0.025^{*}$ & $26.0,21.0-29.3$ & 0.672 & $24.6,18.7-30.4$ & 0.138 \\
\hline $\mathrm{WBC}\left(\mathrm{x} 10^{9} / \mathrm{L}\right)$ & $12.9,4.1-38.3$ & 7.6, $4.0-20.7$ & 0.161 & $8.2,4.1-67.5$ & 0.686 & $7.3,4.4-58.0$ & 0.686 \\
\hline Platelet $\left(\times 10^{9} / \mathrm{L}\right)$ & $294.5,34.0-644.0$ & $316.5,60.0-614.0$ & 0.779 & $417.0,109.0-732.0$ & 0.866 & $256.0,69.0-611.0$ & 0.686 \\
\hline Se.LDH $(\mu / \mathrm{L})$ & $952.5,378.0-1804.0$ & $648.5,364.0-1517.0$ & 0.345 & $483.0,366.0-600.0$ & 0.180 & - & - \\
\hline $\begin{array}{l}\text { Unconjugated } \\
\text { bilirubin }(\mu \mathrm{mol} / \mathrm{L})\end{array}$ & $53.0,40.0-79.0$ & $60.5,43.0-85.0$ & 1.000 & $45.0,32.0-73.0$ & 0.271 & $45.0,32.0-73.0$ & 0.655 \\
\hline Spleen size $(\mathrm{cm})$ & $10.5,5.0-15.0$ & $12.0,4.0-12.0$ & 0.180 & $10.0,2.0-14.5$ & 0.109 & $6.0,4.0-16.0$ & 0.285 \\
\hline \multicolumn{8}{|c|}{$\beta$-thalassemia major (5 patients) } \\
\hline $\mathrm{HbF}(\%)$ & $8.0,3.5-35.0$ & $24.9,6.6-39.0$ & 0.109 & $21.6,3.8-54.1$ & 0.068 & $24.5,4.8-44.2$ & 0.180 \\
\hline $\mathrm{Hb}(\mathrm{g} / \mathrm{dL})$ & $7.3,5.0-8.9$ & $8.7,6.0-11.4$ & $0.043 *$ & $9.5,7.6-12.7$ & 0.109 & $7.9,5.5-9.5$ & 0.109 \\
\hline $\operatorname{MCV}(f l)$ & $78.5,58.6-86.8$ & $81.3,71.4-84.1$ & 0.225 & $79.0,69.3-87.3$ & 0.109 & $77.4,72.7-87.4$ & 0.285 \\
\hline $\mathrm{MCH}(\mathrm{pg})$ & $26.2,17.1-29.9$ & $26.2,22.5-28.6$ & 0.273 & $27.7,23.4-28.9$ & 0.285 & $28.2,23.6-30.2$ & 0.109 \\
\hline $\mathrm{WBC}\left(\mathrm{x} 10^{9} / \mathrm{L}\right)$ & $12.8,4.3-38.7$ & 7.1, $4.5-14.0$ & 0.138 & $6.8,6.5-21.9$ & 1.000 & $4.9,4.5-11.7$ & 0.593 \\
\hline Platelet $\left(\times 10^{9} / \mathrm{L}\right)$ & $233.0,64.0-484.0$ & $190.0,50.0-295.0$ & 0.080 & $149.0,10.7 .0-430.0$ & 1.000 & $126.0,50.0-268.0$ & 0.593 \\
\hline Se.LDH $(\mu / L)$ & $866.0,556.0-1068.0$ & $468.0,431.0-922.0$ & 0.109 & $736.0,315.0-748.0$ & 0.068 & - & - \\
\hline $\begin{array}{l}\text { Unconjugated } \\
\text { bilirubin }(\mu \mathrm{mol} / \mathrm{L})\end{array}$ & $56.0,16.0-89.0$ & $64.0,31.0-85.0$ & 1.000 & $63.0,12.0-81.0$ & 0.144 & $74.0,12.0-76.0$ & 1.000 \\
\hline Spleen size $(\mathrm{cm})$ & $11.0,9.0-13.0$ & $10.0,9.5-11.0$ & 0.285 & $10.5,10.0-11.0$ & 0.180 & - & - \\
\hline
\end{tabular}

${ }^{*} P<0.05$

Table 2. Pre-transfusion data in patients with $\beta$-thalassemias with or without splenectomy treated with HU

\begin{tabular}{|c|c|c|c|c|c|c|c|}
\hline Parameters & $\begin{array}{c}\text { Baseline } \\
\text { (median, range) }\end{array}$ & $\begin{array}{l}3 \text { months on } \mathrm{HU} \\
\text { (median, range) }\end{array}$ & $P$ value & $\begin{array}{l}12 \text { months on HU } \\
\text { (median, range) }\end{array}$ & $P$ value & $\begin{array}{l}18 \text { months on } \mathrm{HU} \\
\text { (median, range) }\end{array}$ & $P$ value \\
\hline \multicolumn{8}{|c|}{ Splenectomized (6 patients) } \\
\hline $\mathrm{HbF}(\%)$ & $7.5,2.5-61.3$ & $15.8,3.4-80.3$ & $0.043 *$ & $13.3,2.6-1.5$ & 0.068 & - & - \\
\hline $\mathrm{Hb}(\mathrm{g} / \mathrm{dL})$ & $8.1,6.5-10.0$ & $9.2,7.6-11.4$ & 0.056 & $8.2,7.4-12.7$ & 0.345 & $8.2,6.9-9.5$ & 0.715 \\
\hline $\operatorname{MCV}(\mathrm{fl})$ & $83.4,79.5-86.8$ & $85.0,78.6-94.2$ & 0.345 & $87.3,77.6-89.5$ & 0.138 & $87.6,81.8-88.7$ & 0.066 \\
\hline $\mathrm{MCH}(\mathrm{pg})$ & $29.3,27.2-30.5$ & $28.9,25.9-34.6$ & 0.600 & $27.7,25.7-29.3$ & $0.043 *$ & $29.3,26.2-30.4$ & 0.465 \\
\hline $\mathrm{WBC}\left(\times 10^{9} / \mathrm{L}\right)$ & $32.3,15.4-38.7$ & $13.0,7.1-20.7$ & $0.046^{*}$ & $24.4,7.5-67.5$ & 0.715 & $17.6,11.7-58.0$ & 0.593 \\
\hline Platelet $\left(\times 10^{9} / \mathrm{L}\right)$ & $459.0,377.0-644.0$ & $424.0,190.0-614.0$ & 0.116 & $484.0,417.0-732.0$ & 0.686 & $483.0,268.0-611.0$ & 0.590 \\
\hline Se.LDH $(\mu / L)$ & $1124.5,392.0-1804.0$ & $780.0,431.0-1517.0$ & 0.893 & - & - & - & - \\
\hline $\begin{array}{l}\text { Unconjugated } \\
\text { bilirubin }(\mu \mathrm{mol} / \mathrm{L})\end{array}$ & $43.0,16.0-79.0$ & $51.0,31.0-63.0$ & 0.715 & $59.0,12.0-73.0$ & 0.345 & - & - \\
\hline \multicolumn{8}{|c|}{ Non-Splenectomized (7 patients) } \\
\hline $\mathrm{HbF}(\%)$ & $26.2,3.5-35.0$ & $31.0,10.0-49.2$ & 0.080 & $37.8,3.8-54.3$ & $0.043 *$ & $37.5,4.8-44.2$ & 0.068 \\
\hline $\mathrm{Hb}(\mathrm{g} / \mathrm{dL})$ & $7.0,5.0-10.0$ & $7.9,6.6-11.0$ & $0.027 *$ & $7.8,7.1-10.5$ & $0.043 *$ & $7.8,5.5-11.2$ & $0.043 *$ \\
\hline MCV (fl) & $71.4,58.6-84.2$ & $84.1,70.0-96.2$ & $0.018 *$ & $75.2,67.2-98.1$ & $0.043 *$ & $73.6,66.8-83.1$ & 0.080 \\
\hline $\mathrm{MCH}(\mathrm{pg})$ & $21.7,17.1-26.6$ & $26.2,21.9-29.6$ & $0.028 *$ & $25.6,21.0-28.9$ & $0.043 *$ & $23.0,18.7-28.2$ & 0.273 \\
\hline $\mathrm{WBC}\left(\times 10^{9} / \mathrm{L}\right)$ & $4.9,4.1-12.8$ & $5.6,4.0-9.8$ & 0.398 & $6.5,4.1-8.8$ & 0.715 & $4.5,4.4-7.3$ & 0.345 \\
\hline Platelet $\left(\times 10^{9} / \mathrm{L}\right)$ & $146.0,34.0-233.0$ & $110.0,50.0-247.0$ & 0.750 & $136.0,107.0-188.0$ & 0.686 & $126.0,50.0-256.0$ & 0.686 \\
\hline Se.LDH $(\mu / L)$ & $761.0,378.0-1144.0$ & $511.0,364.0-922.0$ & 0.500 & $668.0,366.0-748.0$ & 0.144 & $545.0,472.0-618.0$ & 0.144 \\
\hline $\begin{array}{l}\text { Unconjugated } \\
\text { bilirubin }(\mu \mathrm{mol} / \mathrm{L})\end{array}$ & $56.0,42.0-89.0$ & $66.5,43.0-85.0$ & 0.917 & $54.0,41.0-81.0$ & 0.116 & $64.0,40.0-76.0$ & 0.715 \\
\hline Spleen size $(\mathrm{cm})$ & $11.0,5.0-15.0$ & $10.5,4.0-12.0$ & 0.080 & $10.0,2.0-14.5$ & $0.042 *$ & $10.0,4.0-16.0$ & 0.104 \\
\hline
\end{tabular}

${ }^{*} P<0.05$ 


\section{DISCUSSION}

Pharmacological stimulation of $\mathrm{HbF}$ production is of considerable interest as an alternative approach to the therapy of severe thalassemia. Hydroxyurea therapy could increase the $\mathrm{HbF}$ production in $\beta$-thalassemia patients due to an improvement in the $\alpha$ :non- $\alpha$ globin ratio. ${ }^{2,4}$ Hydroxyurea has been shown to increase total $\mathrm{Hb}$ and $\mathrm{HbF}$ levels and reduce the need for blood transfusion in a patient with transfusion-dependent $\beta$ - thalassemia. ${ }^{8}$ In contrast, Loukopoulos et $a l^{9}$ showed that HU therapy resulted in a significant increase in $\mathrm{HbF}$ with no change in total $\mathrm{Hb}$ levels in patients with $\beta$-thalassemia intermedia. Thus, the effectiveness of $\mathrm{HU}$ in the thalassemia syndromes is still controversial.

Our results demonstrated that HU therapy was associated with an improvement in the ineffective erythropoiesis as reflected by an increase in the $\mathrm{Hb}$ level, a reduction in red cell transfusion requirement and a decreasing trend in the serum LDH and serum unconjugated bilirubin levels. This favorable effect of $\mathrm{HU}$ was observed as early as 1 to 3 months of $\mathrm{HU}$ treatment. In contrast, a significant decrease in spleen size reflecting a reduction in extramedullary erythropoiesis appeared to take place much later, after 6 months of HU therapy with a maximal benefit observed at 12 months of HU therapy. These favorable effects of HU appeared to be associated with an increase in the $\gamma$-globin biosynthesis, because the percentage of $\mathrm{HbF}$ increased as well as the total $\mathrm{Hb}$. This observation is in agreement with a short-term study that showed a good correlation of $\mathrm{Hb}$ levels with the amount of $\mathrm{HbF}$ production in patients with $\beta^{0}$-thalassemia/ $\mathrm{HbE}$ treated with HU for 5 months. ${ }^{4}$ However, we showed that the increment in total $\mathrm{Hb}$ became less remarkable after 18 months of HU therapy despite being on a stable dose of HU. Interestingly, while there was a decline in the total $\mathrm{Hb}$, the $\mathrm{HbF}$ level remained elevated. This intriguing observation suggest that increasing $\mathrm{HbF}$ further may not necessarily resulted in a concomitant increase in total $\mathrm{Hb}$ in particular after one year of therapy, and $\mathrm{HbF}$ increment per se is not adequate for maintaining optimum $\mathrm{Hb}$ level in patients with $\beta$ thalassemia. Indeed, the decrement in $\mathrm{Hb}$ level was less likely due to myelotoxicity as there was no concomitant reduction in the leukocyte and platelet counts.

In addition to the modest increase in the $\mathrm{Hb}$, most patients reported an increase in exercise tolerance and sense of well being in comparison with their symptoms before therapy. This feeling may reflect the significant decrease in ineffective erythropoiesis resulting in the replacement of the poorly hemoglobinised, prematurely dying erythroid progenitor and red cell population by another population of cells with higher $\mathrm{Hb}$ content and longer survival, the regeneration of which requires less energy and consumption. ${ }^{9}$ In patients who exhibit a $\beta$ thalassemia intermedia phenotype, even a modest increase in red cell production with coincident reduction in ineffective erythropoiesis might be highly beneficial as the need of red cell transfusion might be delayed or eliminated. We showed that 6 of 7 transfusiondependent patients (5 $\beta$-thalassemia intermedia and one $\beta$-thalassemia major) who experienced an increment of $\mathrm{HbF}$ also had reduced red cell transfusion requirement after HU therapy.

The cutaneous side-effects of $\mathrm{HU}$, which were the commonest side-effects, were seen in only 3 patients, and these resolved by dose modification. The development of adverse cutaneous reactions due to HU appeared to depend on the underlying demographic and medical features of patients. In general, these reactions are more likely to develop in patients with SCD than in thalassemia as patients with SCD have darker baseline pigmentation as well as chronic microangiopathy, putting them at risk for both pigmentary and ulcerative complications. ${ }^{10}$ The maximal tolerated dose of $\mathrm{HU}$ of $25 \mathrm{mg} / \mathrm{kg} / \mathrm{day}$ was achieved by 6 months of HU therapy and importantly, it was not associated with significant myelotoxicity in the majority of patients.

Overall, the outcome of this study on the effects of $\mathrm{HU}$ in a cohort of $\beta$-thalassemia patients has been encouraging. However, 3 patients with $\beta$-thalassemia intermedia did not show a consistent increment in $\mathrm{HbF}$ level. These non-responders might be due to poor compliance or they harbored genetic defects that were different from the responders. It is now very important to determine whether these unusual responses reflect the action of the particular underlying thalassemia mutations ${ }^{11}$ or whether other mechanisms are involved. Another problem, which requires further exploration, is whether a combination of agents that can increase $\mathrm{HbF}$ may be more effective than single agent (examples, erythropoietin and azacytidine), and, if so, the precise regimen of administration of these agents needs to be addressed. Thirdly, it will be interesting to see whether induction of $\mathrm{HbF}$ synthesis in patients with severe $\beta$-thalassemia can eliminate their long-term transfusion requirement.

We conclude that a significant increase in $\mathrm{HbF}$ production in $\beta$-thalassemia patients associated with 
an improvement in erythropoiesis, can be achieved using HU with minimal toxicity. This beneficial effect and safety profile of $\mathrm{HU}$ in this population would need to be confirmed in a further study with a larger number of patients.

\section{Acknowledgements}

We are grateful to Ms. Rozie Hanisa Musa from the National Blood Center, Kuala Lumpur, Malaysia for her excellent technical assistance and Dr. Leong Chooi Fun for his assistance in patient recruitment. This work was supported by grants from the Intensification of Research in Priority Areas (IRPA06-02-02-091) and Hospital Universiti Kebangsaan Malaysia (HUKM F1-99), Kuala Lumpur, Malaysia.

\section{REFERENCES}

1. Kazazian HH, Boehm CD. Molecular basis and prenatal diagnosis of beta-thalassemia. Blood. 1988; 72: 1107-16.

2. Zeng YT, Huang SZ, Ren ZR, Lu ZH, Zeng FY, Schechter AN, et al. Hydroxyurea therapy in betathalassemia intermedia: improvement in hematological parameters due to enhanced beta-globin synthesis. $\mathrm{Br} \mathbf{J}$ Hematol. 1995; 90: 557-63.

3. Schwartz EC, Benz EJ. The Thalassemia syndromes. In: Hoffman R, editor. Hematology: basic principles and practice. $1^{\text {st }}$ ed. New York: Churchill Livingstone; 1991.p.368-91.
4. Fucharoen S, Siritanaratkul N, Winichagoon P, Chowthawom J, Siriboon W, Muangsup W, et al. Hydroxyurea increases hemoglobin $\mathrm{F}$ levels and improves the effectiveness of erythropoiesis in $\beta$-thalassemia/ Hemoglobin E disease. Blood. 1996; 87: 887-92.

5. Charache S, Terrin ML, Moore RD, Dover GJ, Barton FB, Eckert SV, et al. Effect of hydroxyurea on the frequency of painful crises in sickle cell anemia. Investigators of the Multicenter Study of Hydroxyurea in Sickle Cell Anemia. New Engl J Med. 1995; 332; 1317-22.

6. Stamatoyannopoulos JA, Neinhuis AW. Therapeutic approaches to hemoglobin switching in treatment of hemoglobinopathies. Ann Rev Med. 1992; 43: 497-521.

7. Rodgers GP, Dover GJ, Noguchi CT, Schechter AN, Nienhius AW. Hematologic responses of patients with sickle cell disease to treatment with hydroxyurea. New Engl J Med. 1990; 332: 1037-45.

8. Valder R, Carmem SP, Fernando F. Successful use of hydroxyurea in beta-thalassemia major. New Engl $\mathrm{J}$ Med. 1997; 336: 964-5.

9. Loukopoulos D, Voskaridou E, Stomoulakatou A, Papassotiriou Y, Kalotychou V, Loutradi A, et al. Hydroxurea therapy in thalassemia. Ann N Y Acad Sci. 1998; 850: 120-8.

10. Zargari O, Asadi AK, Jafroodi M. Cutaneous adverse reactions to hydroxyurea in patients with intermediate thalassemia. Pediatr Dermatol. 2004; 21: 633-5.

11. Winichagoon $\mathrm{P}$, Thonglairoam V, Fuchareon $\mathrm{S}$, Wilairat $\mathrm{P}$, Fukumaki Y, Wasi P. Severity differences in betathalassemia/HbE syndromes: Implications of genetic factors. Br J Hematol. 1993; 83: 633-53. 